\title{
From Competitive Advantage to Cross-Country Dynamic Synergy
}

\author{
Prof Dr. M S S El Namaki, \\ Victoria University, School of Management, Switzerland
}

\begin{abstract}
The prominence driven home by Porter's gospel or the argument that the ultimate purpose of strategic thinking is achieving long term sustainable competitive advantage within a well-defined industry (Porter 1979), is being challenged and refuted. Competitive advantage is transient, not sustainable (McGrath, 2013). Deeply ingrained structures and systems designed to extract maximum value from a competitive advantage become a liability when the environment requires an agile competence compatible with the rapidly changing opportunity, and threat, landscape. And competitive advantage could relate to yesterday's industries not today's emerging arenas. The need is there for a novel conceptual and operational framework compatible with the transience of advantage and contemporary turbulence of outlook. The following article addresses this need.
\end{abstract}

The article starts with an analysis of the competitive advantage concept and triggers of decay. This is followed by an introduction of a possible substitute: the dynamic synergy analysis, which is an analysis that follows term driving forces among nations and derives synergies and consequent strategies. Case illustrations are then explored in order to demonstrate applicability of the concept. China and Russia were taken as case illustrations.

The article has conceptual an operational benefit. It provides a novel approach to the issue of strategic behaviour under conditions of rapid business and technology change. And it complements the concept with an operational model leading to specific modes of this strategic behaviour.

Paper type: Viewpoint

Keywords: Dynamic Synergy; Strategic Management; Transient Competitive Advantage; Globalisation 


\section{Competitive advantage: the birth and death of a concept}

Strategy according to Porter is tantamount to "building defences against the competitive forces or finding positions in the industry where the forces are the weakest" (Porter, 1979: 143). Porter continues to assert that the "key to growth-even survival-is to stake out a position that is less vulnerable to attack from opponents whether established or new, and less vulnerable to erosion from the direction of buyers, suppliers and substitute goods" (Porter, 1979: 145). In short, the key to business growth is to identify a position that delivers a competitive advantage allowing the organization to outperform its competition. Strategic management should be concerned with building and sustaining competitive advantage (Porter, 1990).

Porter's concepts of strategy, company positioning and competitive advantage were challenged and eventually wore off. Sources of decay varied. There was the contextual and there was the conceptual (El Namaki, 2012).

The contextual flaws related to the political and economic policy forces that existed at the time of conceiving the concept. Porter's conception of competitive advantage took place at a point in time where Reagan was conceiving his deregulation and free capital market policies that undermined all five forces of Porter. Deregulation of capital market changed some of the prime premises of the five forces. Capital triggered $\mathrm{M}$ and A could change seller buyer relationship. Private equity and hedge fund capital could undermine entry barriers. Substitution could become a function of capital input into $R \& D$ and the conversion of $R \& D$ output into viable marketable products (El Namaki, 2012).

As to the conceptual sources of decay the scope is wide. One of the prime five force paradigm flaws is the assumption that barriers would enhance and extend a competitive advantage. Globalization, capital market turbulence, e technologies among several other forces did away with barriers whether psychological or physical. Entry into new markets and new products as much as new entrants abruptly redefined industries. Continuous innovation replaced barrier setting. It created new parameters for industries, products and markets. The model ignored rapid environmental change typical for our times. Those changes emerge as silent or weak signals, as Ansoff came to describe them (Ansoff, 1965), that turn into torrents and powerful forces of change. Nowhere is this noticeable more than in technology and finance. Disruptive technologies emerge at breath taking pace (Christensen et al., 2015). Pertinent competitive advantage is sudden in emergence and short in life time (McGrath, 2013).

\section{Synergy and cross country synergy}

Synergy connotes interaction between two or more inputs in a way that leads to an aggregated output greater than the sum of the individual inputs. Synergy could also be viewed as the creation of a whole that is greater than the simple sum of components. Synergy could add value in terms of structures, innovations, performance and opportunities.

A synergy could exist across countries. Driving forces trigger the process.

International Journal of Management and Applied Research, 2016, Vol. 3, No. 4 
Cross country synergy could be resource driven, efficiency driven or technology driven. Resource driven synergies emerge from natural resource, labor supply and capital asset endowments. Efficiency-driven synergies result from productivity enhancing transformation and market operations. Technology becomes a driving force when novel product, process and market innovations lead to structural industry change (Christensen et al., 2015; Porter and Heppelmann, 2014).

Driving forces could relate to the present or the future. Present day operating conditions could create present day driving forces. Tomorrow's trends or Ansoff's weak signals (Ansoff, 1965), could equally constitute a driving force. The weak signal concept rests on the assumption that discontinuities do not emerge without warning and that timely detection of those warnings or "weak signals" is essential for compatible strategic design.

\section{Synergy analysis}

Dynamic synergy analysis is a process whereby future driving forces of two economies are juxtaposed in order to identify areas of synergy and create a foundation for cross country strategic behaviour (El Namaki, 2016). Synergy connotes, in this case, interaction between two or more forces in a way that leads to a combined output that is greater than the sum of the individual components.

The following graphic representation of the concept projects country future driving force attributes along the $\mathrm{y}$ and $\mathrm{x}$ axis. The $\mathrm{y}$ axis represent the economic driving forces of country A and the $\mathrm{x}$ axis represent the economic driving forces of country $\mathrm{B}$. Synergies between the two respective country specific drivers of economic growth feature in point of intersection between any two drivers.

Figure 1: The Dynamic Synergy Concept

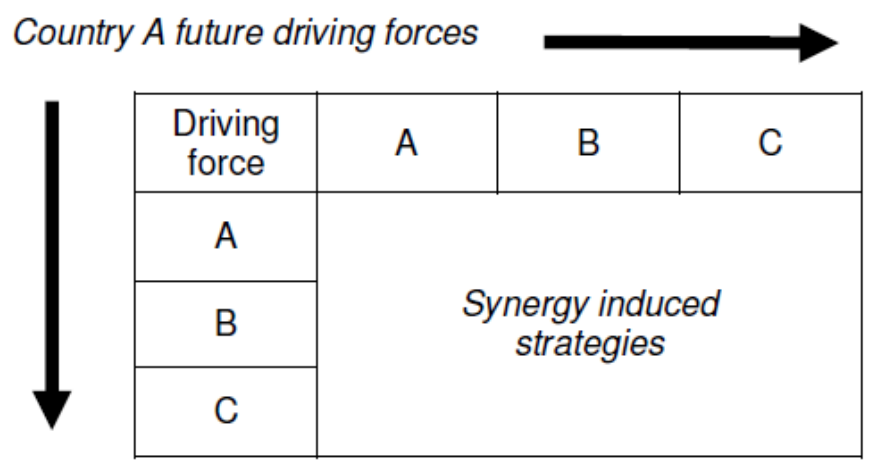

Country B future driving forces

\section{Synergy / Strategy framework}

Synergy congruence could lead to a variety of cross country strategic behaviours. The pattern and contents depend on the measure of synergy and the prospective outcome. The following chart projects two variables: synergy and compatible strategic behaviour. Synergy is given a scale ranging from the low level or basic level to the

International Journal of Management and Applied Research, 2016, Vol. 3, No. 4 
high or wide ranging. Strategic behaviour is also seen as a variable with a selective level and a comprehensive level.

Figure 2: Dynamic Synergy Boundary

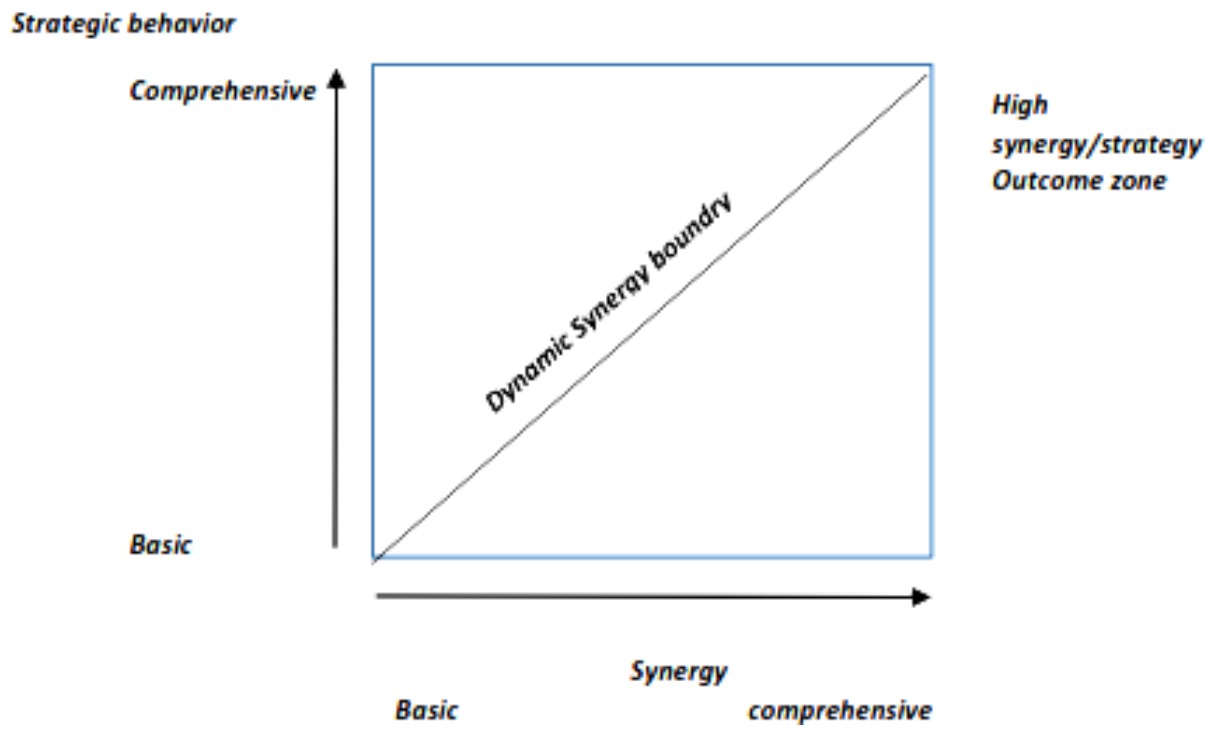

A dynamic synergy boundary could emerge from this juxtaposition. This dynamic boundary projects possible strategic behaviour outcome or outcomes of a given measure of synergy. A comprehensive cross country synergy would lead to comprehensive pattern of strategic behaviour while limited or narrow synergy opportunities lead to an equally basic or low level of strategic behaviour.

The most likely ultimate outcome of a state of comprehensive cross country synergy is a blend of strategies that could extend over a wide front. Their coverage and intensity depend on the scope and extent of the emerging synergy. Prime among those strategic moves are the following.

- Enhancing FDI flows: Investment-rooted synergies could lead to a strategy of enhancing FDI flows in order to acquire a. lasting interest or an effective control over a business entity or an industry operating within a synergy domain.

- Restructuring industries: A cross country industry synergy could induce a restructuring strategy of an industry leading to this industry's life cycle adjustment or even decline.

- Seeking concentration: A synergy could induce a strategy of merger and acquisition and a state of increased concentration or market share dominance by key players.

- Aligning currencies: Synergy between respective country currencies could lead to a strategy of currency swap and possible liberalization of current account and capitalaccount transactions.

- Aligning capital markets: Synergies between respective two country capital markets could lead to a strategy of partial or total integration between key institutional players and a harmonization of policy guidelines.

- Seeking capital market innovation: Capital market synergies could lead to the emergence of products and instruments innovation strategies.

International Journal of Management and Applied Research, 2016, Vol. 3, No. 4 
- Seeking technology congruence: Synergy in specific aspects of technology could encourage strategies of technology upgrade as well as product and process technology shifts.

- Learning: Management and productivity synergy could lead to the adoption of synergy rooted strategies of learning.

- Seeking strategic alliance: Concluding collaborative business arrangements emanating from a synergy in underlying business conditions.

- Seeking trade barrier waivers: Synergy in products and markets could lead to trade liberalization strategies.

Those strategies are by no means exhaustive. Many others patterns of strategic behaviour could emerge given the dynamic nature of the process and the impact of time on synergy dimensions and profile.

\section{Case illustration: China and Russia}

Long and medium term economic driving forces in China cover a wide range but one can identify five key forces: the One Belt One Road initiative (Wilson, 2016), the Asian Infrastructure Investment Bank (Mackintosh, 2016), the internationalization of the RMB (Batten and Szilagyi, 2016), the globalization of capital markets (Black and Morrison, 2010) and the technology surge (Christensen et al., 2015).

The economic future of Russia will, most probably, be defined by five driving forces. Those include the greater reach of Russian energy, the expansive role of minerals and metals industry, and the proliferation of the defence industry, the restructuring of capital markets and the advent of new supply chains (El Namaki, 2016; Fox, 2014; Seitz et al., 2015). Analysis takes into consideration anti-Russian sanctions imposed in the past few years and the tangible recent re-bouncing of the Russian economy (Bozadzhieva, 2016; The Economist, 2015).

Strategic behaviour resulting from cross country synergy in this case could extend of a rather wide range but the ones that come to the forefront are the following:

- Aligning currencies: Synergy within currency markets have led to the setting of currency swap deal between the currencies of the two countries. The deal aims at facilitating bilateral trade and investment between the two countries. The agreement coincides with IMF decision to include China's Rembini in IMF's Special Drawing Right Basket (IMF, 2015; Zhou, 2016).

- Aligning capital investment: Synergies, actual and potential, between respective Russian and Chinese capital markets have led to close cooperation between key banking and finance institutions and a measure of harmonization of policy guidelines (Wilson, 2016). A Russia-China Investment Fund has, for instance, been created in order to capitalize on the rapidly expanding bilateral economic relationship between the two countries (Russia-China Investment Fund, 2012).

- Seeking capital market innovation: Here a search for synergy has led to the creation of novel institutions to complement or replace some of the Western ones i.e. swift code institution.

International Journal of Management and Applied Research, 2016, Vol. 3, No. 4 
The process has, it goes without saying, strong political foundation (El Namaki, 2016; Fox, 2014; Wilson, 2016) and this could explain the rapid development of ideas as well as the rapid implementation of some of those strategies.

\section{Summary and conclusions}

Competitive advantage is officially dead. Prominence driven home by Porters gospel or the argument that the ultimate purpose of strategic thinking is achieving long term sustainable competitive advantage within a well-defined industry is being challenged and refuted. Competitive advantage is transient, not sustainable. Deeply ingrained structures and systems designed to extract maximum value from a competitive advantage become a liability when the environment requires agility which is compatible with the rapidly changing opportunity, and threat, landscape. And competitive advantage could relate to yesterday's industries not today's emerging arenas.

This article suggests a novel conceptual and operational framework compatible with the transience of advantage and contemporary turbulence of outlook. It starts with an analysis of the competitive advantage concept and triggers of decay. This is followed by an introduction of a possible substitute: the dynamic synergy analysis, an analysis that follows term driving forces among nations and derives synergies and consequent strategies. The analysis leads to what we term the synergy strategy boundary or a representation of country strategic behaviour resulting from a given level of synergy. The case of China and Russia illustrates the dynamic synergy mechanism and concludes with a cross country strategic behaviour ranging from enhanced investment flows to capital market integrative modes.

The article has conceptual an operational benefit. It provides a novel approach to the issue of strategic behaviour under conditions of rapid business and technology change. And it complements the concept with an operational model leading to specific modes of this strategic behaviour.

\section{References}

1. Ansoff, H. I. (1965), Corporate Strategy, New York: Wiley.

2. Batten, J. and Szilagyi, P. (2016), "The internationalisation of the RMB: New starts, jumps and tipping points", Emerging Markets Review, Vol. 28, pp. 221-238 https://doi.org/ 10.1016/j.ememar.2016.02.006

3. Black, J. S. and Morrison, A. J. (2010), "A Cautionary Tale for Emerging Market Giants”, Harvard Business Review, Vol. 88, No. 9, pp. 99-103.

4. Bozadzhieva, M. (2016), "Why Multinationals Are Doubling Down on Russia", Harvard Business Review Digital Articles, 4/4/2016, pp. 2-6

5. Christensen, C. M.; Raynor, M. and McDonald, R. (2015), "What is disruptive innovation?", Harvard Business Review, Vol. 93, No. 12, pp. 44-53.

International Journal of Management and Applied Research, 2016, Vol. 3, No. 4 
6. El Namaki M, (2012), "Does the thinking of yesterday's management Gurus imperil today's companies?", Ivey Business Journal, available from: http://iveybusinessjournal.com/publication/does-the-thinking-of-yesterdaysmanagement-gurus-imperil-todays-companies/ [accessed on 30 November 2016].

7. El Namaki M. (2016), "Dynamic synergy analysis in international business: the concept and application to two players China and Russia", Scholedge International Journal of Management \& Development, Vol. 3, No. 7, pp. 129-136.

8. Fox, J. (2014), “An Economic Explanation for Putin's Recklessness”, Harvard Business Review Digital Articles, 8/15/2014, pp. 2-4.

9. International Monetary Fund (2015), IMF Survey: Chinese Renminbi to Be Included in IMF's Special Drawing Right Basket, 1 December, 2015 [Online] available from:

http://www.imf.org/en/News/Articles/2015/09/28/04/53/sonew120115a [accessed on 3 December 2016].

10. Mackintosh, S. M. (2016), "The Creation of the Asian Infrastructure and Investment Bank: America's Loss and China's Gain", World Economics, Vol. 17, No. 3, pp. 25-38.

11. McGrath, R. G. (2013), The End of Competitive Advantage: How to keep your strategy moving as fast as your business, USA: Harvard Business Review Press.

12. Porter, M. (1979), "How competitive forces shape strategy", Harvard Business Review, Vol. 57, No. 2, pp. 137-145.

13. Porter, M. (1985), Competitive Advantage, Free Press.

14. Porter, M. (1990), "The Competitive Advantage of Nations", Harvard Business Review, Vol. 68, No. 2, pp. 73-93.

15. Porter, M. E. and Heppelmann, J. E. (2014), "How Smart, Connected Products Are Transforming Competition", Harvard Business Review, Vol. 92, No. 11, pp. 64-88.

16. Russia-China Investment Fund (2012), About Us, [Online] available from: www.rcif.com [accessed on 3 December 2016].

17. Seitz, M., Tarasov, A. And Zakharenko, R. (2015), "Trade costs, conflicts, and defense spending", Journal Of International Economics, Vol. 95, No. 2, pp. 305318. https://doi.org/10.1016/j.jinteco.2014.11.013

18. The Economist, (2015), "The Russian financial rally", The Economist, 15 Apr 2015, [Online] available from:

http://www.economist.com/blogs/freeexchange/2015/04/russian-financial-rally [accessed on 3 December 2016].

International Journal of Management and Applied Research, 2016, Vol. 3, No. 4 
19. Wilson, J. L. (2016), “The Eurasian Economic Union and China's silk road: implications for the Russian-Chinese relationship", European Politics \& Society, Vol. 17, No. 1, pp. 113-132. https://doi.org/10.1080/23745118.2016.1171288

20. Zhou, X. (2016), "Yuan given to Russia under currency swap deal", South China Morning Post, 2 Mar 2016 [Online] available from:

http://www.scmp.com/business/article/1919707/yuan-given-russia-under-

currency-swap-deal [accessed on 3 December 2016].

International Journal of Management and Applied Research, 2016, Vol. 3, No. 4 